\title{
Hematopoietic Stem Cells Culture, Expansion and Differentiation: An Insight into Variable and Available Media
}

\author{
Pooja Yadav, Ravina Vats, Afsareen Bano, Rashmi Bhardwaj \\ Centre for Medical Biotechnology, Maharshi Dayanand University, Rohtak, India
}

Owing to differentiation and self-renewal capacity, hematopoietic stem cells clasp potentiality to engender all blood cell types, leading to their immense competence to play a diverse role in therapeutic applications. Although these stem cells are the most investigated and exploited until now, further research is still essential to comprehend their nature, fate, and potential. Enhanced usage of hematopoietic stem cells in research and therapeutics intensified the requirement of expansion and differentiation of hematopoietic stem cells under in vitro conditions. Since these cells remain in senescence for a prolonged period before isolation, selection of appropriate growth medium along with supplements and culture conditions are crucial to initiate their cell division and to designate their destiny. The precise equilibrium between self-renewal and differentiation of stem cells sustained by exclusive medium along with special growth or differentiation factors is accountable for generating diverse cell lineages. Maintenance of hematopoietic stem and progenitor cell lines along with the advancement of research work generate an inexorable demand for production and commercialization of specialized stem cell culture media, with or without serum along with specific growth factors and supplements. Media commercialization for precise stem cell types, culturing and differentiation is a cost-effective developing field. Here in this review, we are assembling various types of hematopoietic stem cell self-renewal, expansion and differentiation media along with supplements and culture conditions, either developed and used by various scientists or are available commercially.

Keywords: Hematopoietic stem cell, Media, Culture, Self-renewal, Expansion, Differentiation, Growth factors, Proliferation, Fetal bovine serum

\section{Background}

Stem cells, an emerging tool for regenerative medicine, are disparate from other cell types of our body owing to

Received: December 21, 2019, Revised: July 15, 2020,

Accepted: July 20, 2020, Published online: August 31, 2020

Correspondence to Rashmi Bhardwaj

Centre for Medical Biotechnology, Maharshi Dayanand University, Rohtak 124001, India

Tel: +91-1262-293303, Fax: +91-1262-274640

E-mail: bhardwajrashmi3@gmail.com

(c) This is an open-access article distributed under the terms of the Creative Commons Attribution Non-Commercial License (http://creativecommons.org/ licenses/by-nc/4.0/), which permits unrestricted non-commercial use, distribution, and reproduction in any medium, provided the original work is properly cited.

Copyright (C) 2020 by the Korean Society for Stem Cell Research exclusive properties they embrace. Being unspecialized, these cells retain self-renewal capacity, hence regenerate their pool by cell division; symmetric or asymmetric which further leads to differentiation into diverse cell types. Based on the source of isolation, stem cells can be embryonic, fetal, or adult which can be cord blood, placental, bone marrow (BM), dental, adipose tissue, skin, etc. (1).

Among all the stem cells, hematopoietic stem cells (HSCs), responsible for hematopoiesis in the adult body are the utmost explored and researched one, owing to their enormous potential as well as therapeutic applications. Apart from bone marrow, which is their reservoir, HSCs can also be isolated from granulocyte-colony stimulating factor (G-CSF) mobilized peripheral blood. Also, it is feasible to obtain HSCs and various progenitors of the blood 
cells from fetal as well as embryonic tissues. Moreover, the umbilical cord blood (UCB) and placenta, generally discarded after childbirth, are rich sources of HSCs (2). Somatic cells can also become the source of HSCs by exploiting Induced pluripotent stem cells (IPSCs) (3). HSCs can presumptively characterize and isolated with the help of an anticipated set of clusters of differentiation antigens and cell surface marker present on their cell membrane as predicted and proven by Irving L. Weismann in 1988. These markers change consequently as HSCs get mature and differentiate into a specific set of blood lineages. Human HSCs are identified as Cluster of Differentiation (CD) $34^{+}, \mathrm{CD} 38^{\text {low } /-}, \mathrm{c}-\mathrm{Kit}^{- \text {low }}, \mathrm{CD} 59^{+}, \mathrm{CD}^{+} 0^{+}, \mathrm{Lin}^{-}$ whereas mouse HSCs are recognized as $\mathrm{CD} 34^{\text {low/-}}, \mathrm{CD} 38^{+}$, $\mathrm{c}-\mathrm{Kit}^{+}, \mathrm{SCA}_{-1}^{+}, \mathrm{CD} 90^{+/ \text {low }}, \mathrm{Lin}^{-}$(4).

Carrying the vital capacity to regenerate all blood cell types through making lineage-specific progenitor cells, HSCs are widely used to treat many human disorders (5). Bone marrow transplantations or Hematopoietic stem cell transplantation are HSCs based lifesaving procedures broadly used to treat disease ranging from cancer to autoimmune diseases. Subsequently, potential therapeutics of HSCs is increasing profoundly to life-threatening diseases such as autoimmune disease, leukemia, lymphoma, rheumatoid arthritis, multiple myeloma, hemophilia, diabetes and multiple sclerosis (6-8). Numerous clinical trials have been completed and still ongoing to observe the efficacy of HSCs in treating above mentioned disorders in which either whole BM, progenitors, or purified hematopoietic stem cells have been transplanted in patients and clinical improvement has been observed. However, to the best of our knowledge, none of the clinical studies has used cultured stem cells owing to ethical issues, risk of contamination, knowledge, and availability of suitable media besides culture conditions, etc.

The dynamic implication of HSCs for therapeutics instigates concern to combat the enormous demand of HSCs. Furthermore, whether we are investigating stem cell for fundamental research purpose markedly testing the toxicity of compounds, cancer research, vaccine production, drug screening, and discovery or for future therapeutics, a prerequisite is to culture stem cells under invitro conditions and mimicking similar environment as existing in the individual body from where these cells are isolated (9). Moreover, the accomplishment of a massive supply of HSCs for therapeutic applications demands cells to be expanded, self-renewed, and differentiated under in vitro conditions therefore, the robust HSCs production system is indispensable. However, it is a challenge to culture stem cells as these cells were usually lying quiescent inside their source for a prolonged period and to initiate their cell division with an anticipated output of self-renewal or differentiation in specific lineages is quite challenging. Several factors alike stem cell source, cell count, purification levels like mononuclear fractions, progenitor cells, or highly purified stem cells based on cell surface markers govern the fate of cells in culture.

Stem cell culturing encompasses optimized protocols as well as good quality reagents; however, the most crucial requirement is media which supplies essential components like glucose, vitamins, amino acids, etc., which are vital constituents for the metabolism of stem cells to sustain growth and proliferation (10). Media for stem cell culture not only able to provide elementary nutrients to these cells, but it should also be suited for culture conditions. Pertaining to a fine balance between stem cell self-renewal and lineage commitment, stem cell expansion, as well as differentiation under the in vitro environment, demands a highly controlled system where media along its supplements play a critical and fate-deciding role. Hence, the need for standardization and consistency in stem cell culture medium quality is crucial. Along with media oxygen concentration, cytokine combinations also influence the self-renewal and differentiation potential of HSC's culture under the in vitro condition (11). Various scientists and companies have optimized specialized stem cell culture media and different supplements for specific applications. Here in this review, we have summarized the different types of media developed and used for HSCs culture, self-renewal, expansion, and differentiation into different cell lineages that can be used for either research purpose or therapeutics.

\section{HSCs Culture}

Large numbers of basal media are accessible to culture stem cells, primarily serum-free, although we can include or exclude serum as well as other growth factors based on the requirement. The quality as well as quantity of the serum used in stem cell culture media play a significant role and affect the outputs. Moreover, growth and differentiation factors which are generally recombinant proteins such as Interleukin-3 (IL-3), stem cells factor (SCF), thrombopoietin (TPO), granulocyte-macrophage colony-stimulating factors and erythropoietin, also regulate the survival and self-renewal of HSCs along with proliferation and differentiation (12). These growth factors have an enormous impact on HSCs and their purity, excellence and concentration decide the fate of cultured HSCs (13). Studies of the above-said cytokines used in HSCs culture under in 
vitro conditions shown to have a crucial role as under in vivo condition HSCs are maintained by the SCFs by its c-kit receptor and by the synergic activity of other growth factors which are released by supporting niche cells (14, 15). HSCs also requires TPO for its survival, self-renewal, and platelet production during differentiating into megakaryocytes (16). TPO acts via its myeloproliferative leukemia receptor (17). Numerous types of media and supplements have been exploited in various HSCs studies to maintain self-renewal, proliferation, and culture HSCs under in vitro conditions as discussed.

DMEM is one of the widely used modified versions of Basal Media Eagle's (BME), which comprise of four-fold higher concentrations of vitamins, amino acids, and other supplements than BME. The original formulation of DMEM used $1000 \mathrm{mg} / \mathrm{L}$ glucose, which is predominantly utilized to culture mouse embryonic cells; various modifications of this medium is present nowadays based on the combination of glucose, L-glutamine and sodium pyruvate. Scientists utilized Dulbecco's Modified Eagle's Medium (DMEM) supplemented with valproic acid and $10 \%$ Fetal Bovine Serum (FBS) to culture $\mathrm{CD}_{133}{ }^{+}$lin CD45 ${ }^{-}$hematopoietic cells isolated from umbilical cord blood. In an another study, DMEM supplemented with FBS (15\%), hIL-6 (10 ng/ml), mSCF (100 ng/ml) and mIL-3 (6 ng/ml) has been utilized to culture mouse bone marrow cells (18).

Roswell Park Memorial Institute (RPMI) 1640 media primarily developed by Moore et al., at Roswell Park Memorial Institute, uses a bicarbonate buffering system besides glutathione as a reducing agent. RPMI-1640 has been exploited to culture and increase the yield of Peripheral Blood (PB) mononuclear cells for $5 \sim 7$ days. The media was supplemented with L-glutamine $(200 \mathrm{mmol})$, 2-beta mercaptoethanol (50-mmol), gentamicin $(20 \mu \mathrm{g} / \mathrm{ml})$, FBS (10\%) and growth factors like GM-CSF, IL-4, TNFalpha, IL-1 alpha, IL-1 beta, c-kit ligand, IL-3, M-CSF, IL-2 (19). Iscove's Modified Dulbecco's Medium (IMDM) media, as depicted by Iscove and Guibert, consist of sodium bicarbonate buffered systems besides numerous supplements like albumin, additional amino acids, vitamins, lecithin, selenium and transferrin (20) is another significant HSCs culture media (21). IMDM media along with various combinations of supplements like IL-3 $(5 \mathrm{ng} / \mathrm{ml})$, EPO (3 IU/ml), SCF (100 IU/ml), hydrocortisone (10 $\mu \mathrm{M})$, insulin $(330 \mu \mathrm{g} / \mathrm{ml})$, L-glutamine $(2 \mathrm{mM})$ and human serum has been used in the culturing and the proliferation of CD $45^{+}$cells (22). Along with IMDM, lymphocyte growth media have also been used for the culturing of HSCs along with IMDM media (23).
Although the above discussed basal media are extensively used by numerous stem cell researchers globally, still, precision in stem cell culture requirement has increased tremendously for the last two decades, henceforth necessity of specialized stem cell culture media increases. Apart from the above-mentioned basal media, various specialized media are also currently employed for the HSCs culture, self-renewal, and differentiation. Serum, mostly an animal product utilized along with basal media may pose hazards while culturing human stem cells, especially for therapeutic purposes urges serum-free media utilization. Stem pro-34 SFM one of the specialized serum-free media which is comprised of stem pro basal liquid media along with frozen stem pro-nutrient supplements and is extensively used to support BM, PB, or Cord Blood (CB) hematopoietic stem cells culture, expansion and differentiation (24). Numerous scientific studies have been published where this media has been used to culture hematopoietic stem cells. In one of the study, the $\mathrm{CD} 34^{-/ \text {low }} \mathrm{c}-\mathrm{Kit}^{+} \mathrm{Sca}-1^{+}$ lineage bone marrow cells have been cultured using StemPro-34 SFM supplemented with $0.05 \mathrm{mM} \mathrm{2-} \beta$-mercaptoethanol, $2 \mathrm{mM}$ L-glutamine and cytokines cocktail of mouse SCF (10 ng/ml), mouse IL-3 (10 ng/ml), human TPO (100 ng/ml), human G-CSF (10 ng/ml), human IL$11(100 \mathrm{ng} / \mathrm{ml})$, and human IL-6 (100 ng/ml) till 14 days. Different cytokine cocktail possessed different efficiency in pertaining self-renewal of stem cells, SCF alone increases $25 \%$ of self-renewal but for a limited period of 2 weeks, While TPO alone increases the potential fewer than $10-5 \%$. But the combination of TPO and SCF induced around $90 \%$ potential of cell division. IL-3, IL-6, and G-CSF in combination with SCF significantly increased the potential of cell division to $50 \sim 60 \%$, while alone did not prompt any cell division (25).

\section{HSCs Expansion}

A substantial amount of hematopoietic stem cells is imperative for both stem cell researches as well as for therapeutics and can be acquired through in vitro stem cell expansion which is a long-term culture of HSCs without their exhaustion or differentiation which may happen during HSC culturing. Appropriate culture conditions and expansion media with necessary supplements are prerequisites for this process of continuous maintenance of HSC's features and CD markers. A variety of media has been used for various experimental studies for the expansion of HSCs as described in Table 1 (26-31), many of these are modified basal media and are available commercially too. Stem $\operatorname{Span}^{\mathrm{TM}}$ Serum Free Expansion Media (SFEM) is a 
Table 1. List of different culture media along with supplements for expansion of stem cells from various sources

\begin{tabular}{|c|c|c|c|c|c|c|c|}
\hline Media & $\begin{array}{c}\text { Cell } \\
\text { source }\end{array}$ & Cytokines combinations and supplements & $\begin{array}{l}\text { Phenotypic } \\
\text { markers }\end{array}$ & $\begin{array}{l}\text { No. } \\
\text { of cells }\end{array}$ & $\begin{array}{l}\text { Passage } \\
\text { day }\end{array}$ & $\begin{array}{l}\text { Fold } \\
\text { expansion }\end{array}$ & Ref. \\
\hline SFEM $^{\mathrm{a}}$ & $\mathrm{UCB}^{\mathrm{b}}$ & $\begin{array}{l}100 \mathrm{U} / \mathrm{ml} \mathrm{pen} / \text { strep }+2 \mathrm{mM} \mathrm{L-glut}+25 \mathrm{ng} / \mathrm{ml} \mathrm{SCF}{ }^{\mathrm{c}}+ \\
25 \mathrm{ng} / \mathrm{ml} \mathrm{IL}^{\mathrm{d}}-6+25 \mathrm{ng} / \mathrm{ml} \mathrm{TPO}^{\mathrm{e}}+25 \mathrm{ng} / \mathrm{ml} \mathrm{FLT}^{\mathrm{f}} \text { ligand }\end{array}$ & $\begin{array}{l}\mathrm{CD}^{\mathrm{g}} 34^{+} \\
/ \mathrm{CD} 38^{+}\end{array}$ & $\begin{array}{l}1.0 \times 10^{4} \\
\text { /well }\end{array}$ & 5 days & ND & (26) \\
\hline $\begin{array}{l}\text { Stem Pro } \\
34 \text { SFM }^{\text {h }}\end{array}$ & $\mathrm{UCB}^{\mathrm{b}}$ & $\begin{array}{l}10 \% \mathrm{FBS}^{\mathrm{i}}+100 \mathrm{ng} / \mathrm{mlPen} / \mathrm{Strep}+2 \mathrm{mM} \text { L-glutamine } \\
+\mathrm{hlL}^{\mathrm{d}}-3 \text { peptide } 8+50 \mathrm{ng} / \mathrm{ml} \mathrm{TPO}^{\mathrm{e}}+200 \mathrm{ng} / \mathrm{ml} \mathrm{rhFLT}^{\mathrm{f}}-3\end{array}$ & $\mathrm{CD} 34^{+}$ & $7.3 \times 10^{4}$ & 7 days & 19-fold & (27) \\
\hline $\begin{array}{l}\text { XVIVO } \\
10\end{array}$ & $\mathrm{PBMC}^{\mathrm{j}}$ & $\begin{array}{l}1 \% \text { human serum albumin }+50 \mathrm{ng} / \mathrm{ml} \mathrm{SCF}^{\mathrm{C}}+30 \mathrm{ng} / \mathrm{ml} \\
\mathrm{FLT}^{\mathrm{f}} \text { 3-ligand }+\mathrm{TPO}^{\mathrm{e}}+5-50 \mathrm{ng} / \mathrm{ml} \text { human } \mathrm{IL}^{\mathrm{d}}-3\end{array}$ & CD $34^{+}$ & $2 \times 10^{4}$ & $\begin{array}{l}2 \text { to } 4 \\
\text { days }\end{array}$ & 2.5-fold & (28) \\
\hline $\mathrm{IMDM}^{\mathrm{k}}$ & $\mathrm{UCB}^{\mathrm{b}}$ & $\begin{array}{l}20 \% \mathrm{FBS}^{\mathrm{i}} \text { and } 5 \mathrm{ng} / \mathrm{ml} \mathrm{Se}+50 \mathrm{ng} / \mathrm{ml} \mathrm{TPO}^{\mathrm{e}} \\
\quad+25 \mu \mathrm{g} / \mathrm{ml} \text { insulin }+200 \mu \mathrm{g} / \mathrm{ml} \text { transferrin, } \\
100 \mathrm{ng} / \mathrm{ml} \mathrm{SCF}^{\mathrm{c}}+100 \mathrm{ng} / \mathrm{ml} \mathrm{FLT}^{\mathrm{f}}+10 \mu \mathrm{g} / \mathrm{mL} \mathrm{FA}{ }^{\mathrm{m}}\end{array}$ & $\mathrm{CD} 34^{+}$ & $1 \times 10^{5}$ & 5 days & 20-fold & $(29)$ \\
\hline SFEM $^{\mathrm{a}}$ & $\mathrm{BM}^{\mathrm{n}}$ & 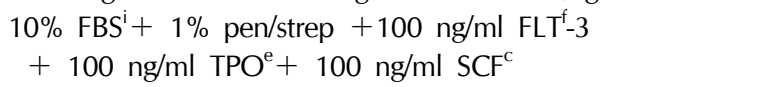 & $\mathrm{CD} 34^{+}$ & $1 \times 10^{5}$ & 24 hours & ND & $(30)$ \\
\hline $\begin{array}{l}\mathrm{HPGM}^{\circ} \\
1640\end{array}$ & ${ }{ }^{\prime} M^{j}$ & $\begin{array}{l}10 \mathrm{FBS}^{\mathrm{i}}+100 \mathrm{U} / \mathrm{ml} \text { Pen/Strep }+100 \mathrm{ng} / \mathrm{ml} \mathrm{SCF}^{\mathrm{c}} \\
+20 \mathrm{ng} / \mathrm{ml} \mathrm{IL}^{\mathrm{d}}-3+30 \mathrm{ng} / \mathrm{ml}\end{array}$ & $\mathrm{CD} 34^{+}$ & $2.5 \times 10^{5}$ & $\begin{array}{l}\text { Up to } 30 \\
\text { days }\end{array}$ & 8-fold & (31) \\
\hline
\end{tabular}

${ }^{\mathrm{a}}$ Serum free expansion medium, ${ }^{\mathrm{b}}$ Umbilical cord blood, ${ }^{\mathrm{c}}$ Stem cell factor, ${ }^{\mathrm{d}}$ Interleukin, ${ }^{\mathrm{e}}$ Thrombopoietin, ${ }_{\mathrm{f}}^{\mathrm{F}} \mathrm{FMS}$ like tyrosine kinase, ${ }^{\mathrm{g}} \mathrm{Cluster}$ of differentiation, 'herum free media, 'Fetal bovine serum, 'Peripheral blood mononuclear cells, 'Iscove's modified dulbecco's medium, 'Selenium, ${ }^{\mathrm{m}}$ Folic acid, "BBone marrow, ${ }^{\mathrm{n}}$ Hematopoietic growth media.

defined, serum-free medium consisting of IMDM, bovine serum albumin, rHuman insulin, human transferrin, 2- $\beta$ mercaptoethanol, and supplements. In one of the study $1 \times 10^{5}$ lin $^{-}$cells $/ \mathrm{ml}$ isolated from UCB have been cultured in SFEM with SCF (100 ng/ml), of Flt-3L (100 ng/ml), TPO $(50 \mathrm{ng} / \mathrm{ml})$ and low-density lipoproteins $(1 \mu \mathrm{g} / \mathrm{ml})$ for 8 days in the primary culture bag. The media was changed every four days and the resultant culture conditions lead to 3.3-fold expansion of HSCs (32). In another study, StemSpan medium supplemented with cytokine cocktail of SCF (100 ng/ml), TPO (100 ng/ml), Flt-3L $(100 \mathrm{ng} / \mathrm{ml})$, resveratrol $(10 \mathrm{mM})$ and IL-6 $(100 \mathrm{ng} / \mathrm{ml})$ was utilized to expand HSCs which were later transplanted in mice model. Resveratrol maintained the HSCs phenotype, enhanced the expansion and engraftment potential of cultured HSCs (33). Likewise, SFEM II which is a modified version of SFEM also utilized to expand HSCs (26). Stem Pro SFM, a widely used media for HSCs culturing purposes and seems valuable for HSCs expansion. Stem pro-34 SFM along with FBS (10\%), L-glutamine (2 $\mathrm{mM})$, TPO (50 ng/ml), rhIL-3 (200 ng/ml) and rhFlt-3L $(200 \mathrm{ng} / \mathrm{ml})$ has been utilized for the expansion of UCB cells (27). In the experimentation, IL-3 enhanced the proliferation and expansion of HSCs (18). In another study Stem pro media was used to proliferate erythroid precursor cells (34).

Hematopoietic Progenitor Growth Media (HPGM) is another specialized expansion media, which is xeno-free media, includes albumin, recombinant insulin, and pasteurized transferrin. HPGM is well suited for the ex- pansion, growth, and differentiation of HSCs as well as hematopoietic progenitor cells from various sources (35). In one of the studies done by Kishimoto et al (36), HPGM media supplemented with $1 \times$ antibiotics/antimycotic solution, FBS (4\%) and cytokine cocktail of TPO (20 ng/ml), Flt-3L $(20 \mathrm{ng} / \mathrm{ml})$ and SCF $(10 \mathrm{ng} / \mathrm{ml})$ with has been used for the culturing of $1 \times 10^{5} \mathrm{BM}$ cells of the mouse $/ 12$ well plate, coated with low molecular weight heparin/protamine microparticles. The cells were cultured for 8 days under the above-said culture condition, and after 8 days there were 11-fold expansions of CD $34+$ stem cells. The coated plates enhanced the expansion of CD $34+$ stem cells by controlling the release of cytokines.

An auxiliary specialized media for HSCs expansion under in vitro condition is Stemline II Hematopoietic stem cell expansion media. This media is a modified version of Stemline media; hence it is a second-generation media that is generated to increase cell expansion besides to optimize the balance of differentiated and undifferentiated cells (37). Although human serum albumin is present, this is serum-free and xeno-free media with no animal-derived constituents. Ficoll sorted BM and $\mathrm{PB} \mathrm{CD} 34^{+} \mathrm{CD} 38^{-}$cells from CML patients have been expanded using Stemline II media, supplemented with cytokine cocktail of TPO (20 $\mathrm{ng} / \mathrm{ml})$, SCF $(100 \mathrm{ng} / \mathrm{ml})$ and Flt-3L $(100 \mathrm{ng} / \mathrm{ml})$ in absence of retinoic acid. The absence of retinoic acid in the culture condition leads to an increase in the expansion of HSC's and its self -renewal ability (38). In a yet another study the Stemline II media supplemented with human SCF (150 ng/ml), Flt-3L (100 ng/ml), IL-3 (50 ng/ml), 
TPO (100 ng/ml) and valproic acid $(1 \mathrm{mM})$ was used to expand the $\mathrm{CD} 34^{+} \mathrm{CD} 38^{-}$cells for 7 days. Along with cytokine cocktail, valproic acid via inhibiting the histone deacetylase activity, shown to have a prominent role in HSCs cell survival and expansion (39).

$\mathrm{X}$-VIVO hematopoietic cell medium is a specialized Serum-free chemically defined media, devoid of any exogenous growth factors, undefined or artificial stimulators, provides a balanced and complete environment for culturing HSCs (40). In one of the stem cell expansion studies, $\mathrm{CD} 34+\mathrm{PB}$ mononuclear cells have been cultured to expand into X-VIVO 10 media supplemented with human SCF (50 ng/ml), 1\% serum albumin and cytokine cocktail of human IL-3, Flt-3L, and TPO (28).

\section{HSCs Differentiation}

Each type of stem cell requires an exclusive culture medium supplemented with specific growth factors to sustain cell proliferation and differentiation into precise lineages. HSCs differentiate in all mature blood cell lineages and this differentiation process is earnestly regulated by intracellular signaling pathways which in turn governed by growth factors and cytokines. Various scientific studies involving in vitro HSCs differentiation into particular lineages, blood, or other tissue types, indicate the use of numerous basal as well as specialized media along with several supplements including cytokines and growth factors cocktails under stringent culture conditions as depicted in Fig. 1 (19, 41-43).

In one of the granulocyte-monocyte to dendritic cells differentiation study, BM cells were cultured in RPMI-1640,

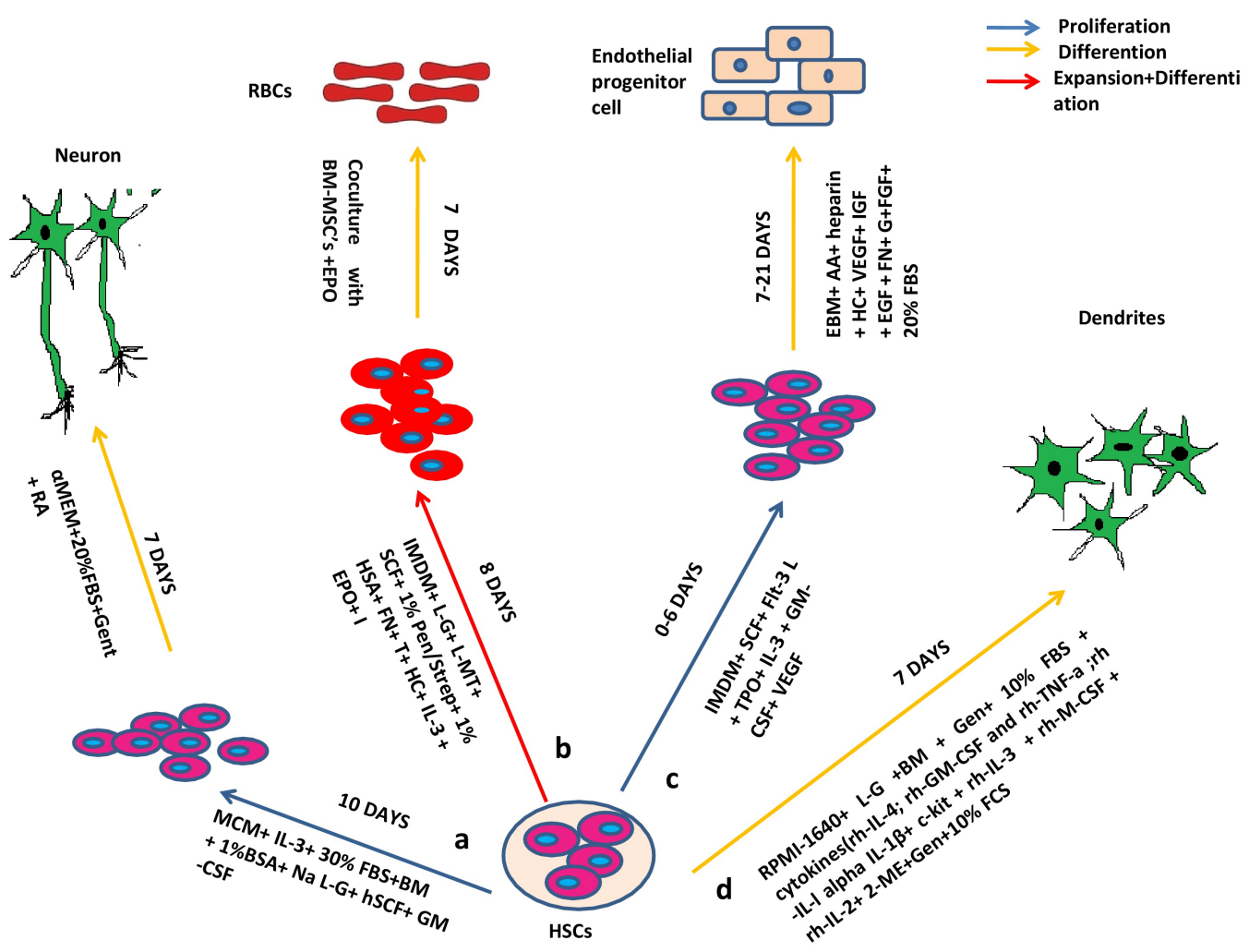

Fig. 1. HSCs differentiation into various lineages. (a) Neuronal differentiation using Methylcellulose (MCM) and $\alpha$-MEM with Interleukin-3(IL-3), $\beta$ - Mercaptoethanol (BM), $1 \%$ bovine serum albumin (BSA), sodium L-glutamine (Na L-G), human recombinant SCF, GM-CSF, $20 \%$ FBS, Gentamicin (Gent) and Retinoic acid (42). (b) Red Blood Cells (RBCs) differentiation using IMDM with L- Glutamine (L-G), L-monothioglycerol (L-MT), SCF., 1\% Pen/Strep, 1\% Human serum albumin (HAS), Ferric nitrate (FN), Transferrin (T), Hydrocortisone (HC), IL-3, Erythropoietin (EPO), Insulin (I) and BM-MSCs (43). (C) Endothelial Progenitor cells differentiation using IMDM and essential basal medium (EBM), SCF+, Flt-3 L, Thrombopoietin (TPO), IL-3, GM-CSF, Vascular endothelial growth factor (VEGF), Ascorbic acid (AA), heparin, Hydrocortisone (HC), IGF, EGF, Ferric nitrate (FN), L- GlutamineL-G and FGF (41). (d) Dendritic cells differentiation using RPMI-1640, L- GlutamineL-G, $\beta$-Mercaptoethanol (BM), Gentamicin (Gent), human recombinant (rh)-IL-4, rh-GM-CSF, rh-Tumor necrosis factor alpha (TNF-a) rh-IL-I $\alpha$, IL-1 $\beta$, c-kit, rh-IL-3, rh-M-CSF, rh-IL-2 (19). 
supplemented with $1 \times$ streptomycin/penicillin, FBS (10\%) and GM-CSF $(20 \mathrm{ng} / \mathrm{ml})$ for 6 days. After 6 days the induced cells were cultured in IMDM supplemented with 1x penicillin/streptomycin, 10\% FBS, Flt-3L $200 \mathrm{ng} / \mathrm{ml}$, mercaptoethanol $(50 \mu \mathrm{M})$ and sodium pyruvate $(1 \mathrm{mM})$ (44). RPMI1640 is also used for the differentiation of HSCs into insulin-producing cells (45). IMDM has already been used for a variety of cells like hematopoietic stem progenitor cells from bone marrow, B-lymphocytes, $\mathrm{T}$ lymphocytes, B cells stimulated with lipopolysaccharide, etc. In another study where an attempt has been made to differentiate $\mathrm{CB}$ CD $34^{+}$cells into endothelial progenitors cells, for proliferation phase, $2 \times 10^{5} \mathrm{CD} 34^{+}$cord blood cells $/ \mathrm{ml}$ were placed in IMDM containing cytokines cocktail of IL-3 (10 ng/ml), SCF (200 ng/ml), Vascular Endothelial Growth Factor (VEGF) (50 ng/ml), Flt-3 L (200 ng/ml), TPO (20 ng/ml), and GM-CSF (12.5 ng/ml), seeded into the 24-well plates and the cells were sub-cultured when the cell density reached $1 \times 10^{6}$ cells $/ \mathrm{ml}$. These cells were further expanded and differentiated into endothelial progenitor cells (41). Moreover, using IMDM media megakaryocytes have been generated from mobilized PB and hematopoietic progenitor cells from BM (46).

X-VIVO 10, a widely HSCs expansion media can also be utilized by expanding cells for differentiation purposes. In a study conducted by Stec et al (47), X-VIVO 10 media supplemented with $4 \%$ of fetal calf serum (FCS), TPO (15 $\mathrm{ng} / \mathrm{ml}$ ), Flt-3L (30 ng/ml), SCF (50 ng/ml), IL-3 (30 ng/ml) was used as the first step for the expansion of CB hematopoietic $\mathrm{CD} 34^{+}$mononuclear cells. Every 3 to 5 days the cells were sub-cultured and enriched with fresh media.
These expanded cells were later differentiated into monocytes by using IMDM media supplemented with SCF (25 $\mathrm{ng} / \mathrm{ml}$ ), IL-3 (30 ng/ml), 20\% FCS, monocyte colony-stimulating factor $(30 \mathrm{ng} / \mathrm{ml})$, Flt-3L (30 ng/ml) for 3 14 days.

Methylcellulose is also one of the varieties of diverse media available for in vitro culturing of HSCs and progenitor cells. Methylcellulose is used to enumerate the mature differentiated blood lineage generating capacity of HSCs, which is known as Colony-forming cell assay which generates colony-forming erythroid, myeloid, and mixed lineage progenitors (48). This media provides diverse progeny on different regions of the plate and thus, it is easy to distinguish the mixture of progenitors generated from the HSCs. Methocult is the variant of methylcellulose media used in several stem cell studies (49). Human methylcellulose enriched media is also a modification of methylcellu-

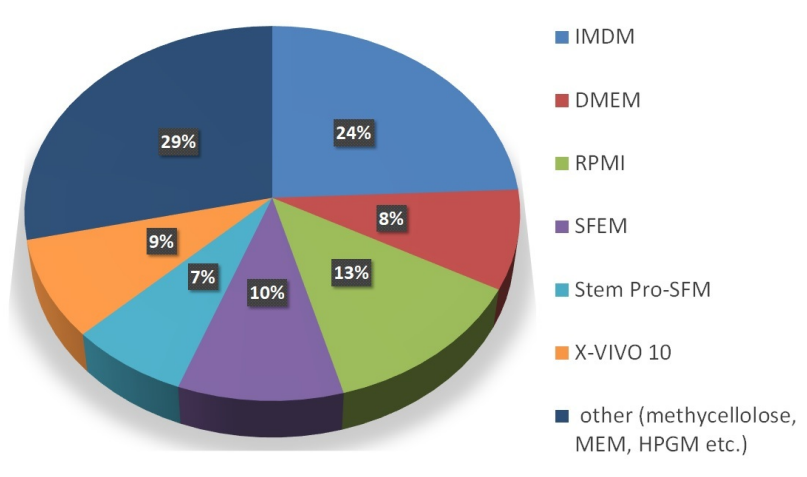

Fig. 2. Pie chart depicting percentage distribution: various culture media for HSC proliferation, expansion and differentiation based on hematopoietic research papers included in this review.

Table 2. Different stem cell media and their commercial suppliers

\begin{tabular}{|c|c|}
\hline Media & Name of the suppliers/company \\
\hline AIM V (19) & Invitrogen \\
\hline $\operatorname{DMEM}^{\mathrm{a}}(21)$ & $\begin{array}{l}\text { Lonza, Thermofischer, Hyclone, Biochrom, Sigma-Aldrich, Cellgro, GIBCO } \\
\text { Invitrogen, STEMCELL Technologies, BioWhittaker, PAN Biotech etc. }\end{array}$ \\
\hline $\mathrm{LGM}^{\mathrm{C}}-3(23)$ & Clonetics Corp., Walkersville \\
\hline StemPro $\mathrm{CD}^{\mathrm{d}} 34^{+}(25)$ & Thermofischer, Gibco \\
\hline Stem X-VIVO (28) & Lonza \\
\hline $\operatorname{IMDM}^{\mathrm{b}}(29)$ & Thermo Fischer, Lonza, Himedia, Gibco, ATCC, Life Technologies \\
\hline Stemspan SFEM ${ }^{\mathrm{e}}$ and SFEM II (30) & STEMCELL Technologies \\
\hline $\operatorname{HPGM}^{f}(31)$ & Lonza \\
\hline Stemline and Stemline II (38) & Sigma \\
\hline Alpha-MEM ${ }^{g}(41)$ & $\begin{array}{l}\text { American Type Culture Collection, BioWhittaker, Gemini Bio-Products, HaartBio } \\
\text { Ltd, Gibco, Lonza, Mediatech, Irvine Scientific and Sigma etc. }\end{array}$ \\
\hline $\mathrm{RPMI}^{\mathrm{h}}(45)$ & $\begin{array}{l}\text { GIBCO Invitrogen, HiMedia, Biochrom, BioWhitaker, Cambrex, STEMCELL } \\
\text { Technologies, Cellgro, Biowest, CRUK, HyClone, ATCC, Irvine, Lonza, Gibco etc. }\end{array}$ \\
\hline
\end{tabular}

${ }^{\mathrm{a}}$ Dulbecco's modified eagle's media, ${ }^{\mathrm{b}}$ Iscove's modified dulbecco's medium, 'Lymphocyte growth factor, ${ }^{\mathrm{d} C l u s t e r}$ of differentiation, ${ }^{\mathrm{e}}$ serum free expansion media, ${ }^{\mathrm{f}}$ Hematopoietic growth media, ${ }^{\mathrm{g}}$ Minimal essential medium, ${ }^{\mathrm{h}}$ Roswell park memorial institute. 
lose and is used to distinguish the mixed cell population into respective progenitors. For the assay of erythroid, myeloid, and mixed lineage progenitors from a BM isolated mixed $\operatorname{lin}^{-}$sample, $0.8 \%$ methylcellulose in the alpha medium was used in a study done by Lemieux $M$ et al. The cells were cultured along with the various supplemented such as $1 \%$ bovine serum albumin, 30\% FCS, 0.1 $\mathrm{mmol} / \mathrm{L} \beta$ mercaptoethanol, $2 \%$ pokeweed mitogen-stimulated mouse spleen cell-conditioned media and $3 \mathrm{U} / \mathrm{ml}$ human erythropoietin. The cells were assayed after 14 days (50).

\section{Conclusions}

Stem cells are an emerging therapeutic tool to cure numerous life-threatening human ailments. With escalating research and clinical use, rises the need for a large amount of stem cells, which can significantly fulfill through stem cell culture under in vitro conditions in which culture media plays an imperative role. Stem cell culture media has diverse applications and utilities ranging from self-renewal, proliferation, expansion, and differentiation. For reproducible results in stem cell experiments meant for research purposes as well as therapeutics, one must use quality controlled standard media which will enhance the validity and consistency in this highly desirable field. Media has been formalized from time to time as per the need for stem cells to deliver an improved in vitro environment for stem cell development. Numerous scientists in addition to biological industries are continuously moving forward in this direction and formulating improved as well as ready to use appropriate stem cell culture media. It is mandatory to observe stem cell behavior and culture condition requirements while culturing cells either in basal media with various supplements or commercially available specialized medium.

Here in this review we have summarized diverse kinds of media available and used by several scientific groups for in vitro culturing HSCs. We have cited most of the media available and used in culturing hematopoietic stem cells along with the commercial suppliers as given in Table 2. As per the analysis of various HSCs culturing media in this review article, depicted in Fig. 2 it has been noted that IMDM and RPMI are extensively exploited basal media, also X-VIVO, SFEM are the foremost used serum-free specialized media. Keeping in mind the experiments and applications of HSCs culture, stem cell researchers can choose from the conferred media in this article. However, stem cell scientific community need more derived media for the efficient culturing of HSCs, so that researchers can work on stem cell field proficiently and exploit the field extensively.

\section{Acknowledgments}

We thank Centre for Medical Biotechnology Maharshi Dayanand University Rohtak for providing support to accomplish this work.

\section{Potential Conflict of Interest}

The authors have no conflicting financial interest.

\section{Author Contributions}

PY collected literature and wrote the manuscript. RV edited and revised the manuscript. $\mathrm{AB}$ revised the manuscript. RB designed, wrote, edited and prepared the manuscript for submission. All authors read and approved the final manuscript.

\section{References}

1. Rajabzadeh N, Fathi E, Farahzadi R. Stem cell-based regenerative medicine. Stem Cell Investig 2019;6:19

2. Abdulrazzak H, Moschidou D, Jones G, Guillot PV. Biological characteristics of stem cells from foetal, cord blood and extraembryonic tissues. J R Soc Interface 2010; 7(Suppl 6):S689-S706

3. Vo LT, Daley GQ. De novo generation of HSCs from somatic and pluripotent stem cell sources. Blood 2015;125: 2641-2648

4. Spangrude GJ, Heimfeld S, Weissman IL. Purification and characterization of mouse hematopoietic stem cells. Science 1988;241:58-62

5. Chivu-Economescu M, Rubach M. Hematopoietic stem cells therapies. Curr Stem Cell Res Ther 2017;12:124-133

6. Burt RK, Slavin S, Burns WH, Marmont AM. Induction of tolerance in autoimmune diseases by hematopoietic stem cell transplantation: getting closer to a cure? Blood 2002;99: 768-784

7. Verburg RJ, Kruize AA, van den Hoogen FH, Fibbe WE, Petersen EJ, Preijers F, Sont JK, Barge RM, Bijlsma JW, van de Putte LB, Breedveld FC, van Laar JM. High-dose chemotherapy and autologous hematopoietic stem cell transplantation in patients with rheumatoid arthritis: results of an open study to assess feasibility, safety, and efficacy. Arthritis Rheum 2001;44:754-760

8. Muraro PA, Uccelli A. Immuno-therapeutic potential of haematopoietic and mesenchymal stem cell transplantation in MS. Results Probl Cell Differ 2010;51:237-257

9. Kumar S, Geiger H. HSC niche biology and HSC expansion ex vivo. Trends Mol Med 2017;23:799-819

10. Ito K, Suda T. Metabolic requirements for the maintenance of self-renewing stem cells. Nat Rev Mol Cell Biol 2014; 15:243-256

11. Kobayashi H, Morikawa T, Okinaga A, Hamano F, 
Hashidate-Yoshida T, Watanuki S, Hishikawa D, Shindou H, Arai F, Kabe Y, Suematsu M, Shimizu T, Takubo K. Environmental optimization enables maintenance of quiescent hematopoietic stem cells ex vivo. Cell Rep 2019;28: 145-158.e9

12. Zhang CC, Lodish HF. Cytokines regulating hematopoietic stem cell function. Curr Opin Hematol 2008;15:307-311

13. Gonçalves AI, Rodrigues MT, Lee SJ, Atala A, Yoo JJ, Reis RL, Gomes ME. Understanding the role of growth factors in modulating stem cell tenogenesis. PLoS One 2013;8: e83734

14. McNiece IK, Briddell RA. Stem cell factor. J Leukoc Biol 1995;58:14-22

15. Ding L, Saunders TL, Enikolopov G, Morrison SJ. Endothelial and perivascular cells maintain haematopoietic stem cells. Nature 2012;481:457-462

16. O'Neill A, Chin D, Tan D, Abdul Majeed AQBB, Nakamura-Ishizu A, Suda T. Thrombopoietin maintains cell numbers of hematopoietic stem and progenitor cells with megakaryopoietic potential. Haematologica 2020 doi: 10.3324/haematol.2019.241406. [Epub ahead of print]

17. Yoshihara H, Arai F, Hosokawa K, Hagiwara T, Takubo K, Nakamura Y, Gomei Y, Iwasaki H, Matsuoka S, Miyamoto K, Miyazaki H, Takahashi T, Suda T. Thrombopoietin/MPL signaling regulates hematopoietic stem cell quiescence and interaction with the osteoblastic niche. Cell Stem Cell 2007;1:685-697

18. Antonchuk J, Sauvageau G, Humphries RK. HOXB4-induced expansion of adult hematopoietic stem cells ex vivo. Cell 2002;109:39-45

19. Morse MA, Zhou LJ, Tedder TF, Lyerly HK, Smith C. Generation of dendritic cells in vitro from peripheral blood mononuclear cells with granulocyte-macrophage-colony-stimulating factor, interleukin-4, and tumor necrosis factor-alpha for use in cancer immunotherapy. Ann Surg 1997;226:6-16

20. Iscove NN, Guilbert LJ, Weyman C. Complete replacement of serum in primary cultures of erythropoietin-dependent red cell precursors (CFU-E) by albumin, transferrin, iron, unsaturated fatty acid, lecithin and cholesterol. Exp Cell Res 1980;126:121-126

21. Bruns I, Cadeddu RP, Brueckmann I, Fröbel J, Geyh S, Büst S, Fischer JC, Roels F, Wilk CM, Schildberg FA, Hünerlitürkoglu AN, Zilkens C, Jäger M, Steidl U, Zohren F, Fenk R, Kobbe G, Brors B, Czibere A, Schroeder T, Trumpp A, Haas R. Multiple myeloma-related deregulation of bone marrow-derived CD $34^{+}$hematopoietic stem and progenitor cells. Blood 2012;120:2620-2630

22. Caminal M, Labrozzi JP, Oliver-Vila I, Alzaga-Gragera $M$, Marín-Gallén S, Pla A, García J, Vives J. Ex vivo production of red blood cells from human cord blood. BMC Proc 2015;9(Suppl 9):P67

23. Goldfarb AN, Wong D, Racke FK. Induction of megakaryocytic differentiation in primary human erythroblasts: a physiological basis for leukemic lineage plasticity. Am J Pathol 2001;158:1191-1198

24. Ando K, Yahata T, Sato T, Miyatake H, Matsuzawa H, Oki
M, Miyoshi H, Tsuji T, Kato S, Hotta T. Direct evidence for ex vivo expansion of human hematopoietic stem cells. Blood 2006;107:3371-3377

25. Ema H, Takano H, Sudo K, Nakauchi H. In vitro self-renewal division of hematopoietic stem cells. J Exp Med 2000;192:1281-1288

26. Yang Y, Wang S, Miao Z, Ma W, Zhang Y, Su L, Hu M, Zou J, Yin Y, Luo J. miR-17 promotes expansion and adhesion of human cord blood CD $34^{+}$cells in vitro. Stem Cell Res Ther 2015;6:168

27. Ren Z, Zhang Y, Zhang Y, Jiang W, Dai W, Ding X, Jiang Y. Influence of IL-3 functional fragment on cord blood stem cell ex vivo expansion and differentiation. Stem Cell Investig 2016;3:6

28. Merling RK, Sweeney CL, Choi U, De Ravin SS, Myers TG, Otaizo-Carrasquero F, Pan J, Linton G, Chen L, Koontz S, Theobald NL, Malech HL. Transgene-free iPSCs generated from small volume peripheral blood nonmobilized CD34 ${ }^{+}$cells. Blood 2013;121:e98-e107

29. Zhang Y, Wang C, Wang L, Shen B, Guan X, Tian J, Ren Z, Ding X, Ma Y, Dai W, Jiang Y. Large-scale ex vivo generation of human red blood cells from cord blood CD34 cells. Stem Cells Transl Med 2017;6:1698-1709

30. Aguila JR, Liao W, Yang J, Avila C, Hagag N, Senzel L, Ma Y. SALL4 is a robust stimulator for the expansion of hematopoietic stem cells. Blood 2011;118:576-585

31. Brown G, Marchwicka A, Cunningham A, Toellner KM, Marcinkowska E. Antagonizing retinoic acid receptors increases myeloid cell production by cultured human hematopoietic stem cells. Arch Immunol Ther Exp (Warsz) 2017; 65:69-81

32. Madlambayan GJ, Rogers I, Purpura KA, Ito C, Yu M, Kirouac D, Casper RF, Zandstra PW. Clinically relevant expansion of hematopoietic stem cells with conserved function in a single-use, closed-system bioprocess. Biol Blood Marrow Transplant 2006;12:1020-1030

33. Heinz N, Ehrnström B, Schambach A, Schwarzer A, Modlich U, Schiedlmeier B. Comparison of different cytokine conditions reveals resveratrol as a new molecule for ex vivo cultivation of cord blood-derived hematopoietic stem cells. Stem Cells Transl Med 2015;4:1064-1072

34. Huang X, Shah S, Wang J, Ye Z, Dowey SN, Tsang KM, Mendelsohn LG, Kato GJ, Kickler TS, Cheng L. Extensive ex vivo expansion of functional human erythroid precursors established from umbilical cord blood cells by defined factors. Mol Ther 2014;22:451-463

35. Rizo A, Dontje B, Vellenga E, de Haan G, Schuringa JJ. Long-term maintenance of human hematopoietic stem/progenitor cells by expression of BMI1. Blood 2008;111:26212630

36. Kishimoto S, Ishihara M, Kanatani Y, Nambu M, Takikawa M, Sumi Y, Nakamura S, Mori Y, Hattori H, Tanaka Y, Sato T. Selective expansion of CD34+ cells from mouse bone marrow cultured on LH/P MP-coated plates with adequate cytokines. J Tissue Eng 2011;2:2041731411425419

37. Choong ML, Yang HH, McNiece I. MicroRNA expression 
profiling during human cord blood-derived CD34 cell erythropoiesis. Exp Hematol 2007;35:551-564

38. Ghiaur G, Yegnasubramanian S, Perkins B, Gucwa JL, Gerber JM, Jones RJ. Regulation of human hematopoietic stem cell self-renewal by the microenvironment's control of retinoic acid signaling. Proc Natl Acad Sci U S A 2013;110: 16121-16126

39. Zimran E, Papa L, Djedaini M, Patel A, Iancu-Rubin C, Hoffman R. Expansion and preservation of the functional activity of adult hematopoietic stem cells cultured ex vivo with a histone deacetylase inhibitor. Stem Cells Transl Med 2020;9:531-542

40. Huang J, Nguyen-McCarty M, Hexner EO, Danet-Desnoyers G, Klein PS. Maintenance of hematopoietic stem cells through regulation of Wnt and mTOR pathways. Nat Med 2012;18:1778-1785

41. Qin M, Guan X, Wang H, Zhang Y, Shen B, Zhang Q, Dai W, Ma Y, Jiang Y. An effective ex-vivo approach for inducing endothelial progenitor cells from umbilical cord blood CD34 ${ }^{+}$cells. Stem Cell Res Ther 2017;8:25

42. Jang YK, Park JJ, Lee MC, Yoon BH, Yang YS, Yang SE, Kim SU. Retinoic acid-mediated induction of neurons and glial cells from human umbilical cord-derived hematopoietic stem cells. J Neurosci Res 2004;75:573-584

43. Baek EJ, Kim HS, Kim S, Jin H, Choi TY, Kim HO. In vitro clinical-grade generation of red blood cells from human umbilical cord blood CD34+ cells. Transfusion 2008; 48:2235-2245

44. Onodera K, Fujiwara T, Onishi Y, Itoh-Nakadai A, Okitsu
Y, Fukuhara N, Ishizawa K, Shimizu R, Yamamoto M, Harigae H. GATA2 regulates dendritic cell differentiation. Blood 2016;128:508-518

45. Kyventidis A, Tzimagiorgis G, Didangelos T. Peripheral blood monocytes can differentiate into efficient insulinproducing cells in vitro. Hippokratia 2015;19:344-351

46. Guerriero R, Testa U, Gabbianelli M, Mattia G, Montesoro E, Macioce G, Pace A, Ziegler B, Hassan HJ, Peschle C. Unilineage megakaryocytic proliferation and differentiation of purified hematopoietic progenitors in serum-free liquid culture. Blood 1995;86:3725-3736

47. Stec M, Weglarczyk K, Baran J, Zuba E, Mytar B, Pryjma J, Zembala M. Expansion and differentiation of $\mathrm{CD}^{+}{ }^{+}$ $\mathrm{CD}_{16}{ }^{-}$and $\mathrm{CD} 14^{+}{ }^{+} \mathrm{CD} 16^{+}$human monocyte subsets from cord blood CD $34^{+}$hematopoietic progenitors. J Leukoc Biol 2007;82:594-602

48. Wognum B, Yuan N, Lai B, Miller CL. Colony forming cell assays for human hematopoietic progenitor cells. Methods Mol Biol 2013;946:267-283

49. Vodyanik MA, Thomson JA, Slukvin II. Leukosialin (CD43) defines hematopoietic progenitors in human embryonic stem cell differentiation cultures. Blood 2006;108: 2095-2105

50. Lemieux ME, Rebel VI, Lansdorp PM, Eaves CJ. Characterization and purification of a primitive hematopoietic cell type in adult mouse marrow capable of lymphomyeloid differentiation in long-term marrow "switch" cultures. Blood 1995;86:1339-1347 